\title{
LUT
}

University

\section{Structure of intellectual capital - an international comparison}

Inkinen Henri, Kianto Aino, Vanhala Mika, Ritala Paavo

This is a Final draft version of a publication

published by Emerald Publishing

in Accounting, Auditing and Accountability Journal

DOI: $10.1108 /$ AAAJ-11-2015-2291

Copyright of the original publication: ( 2017, Emerald Publishing Limited

Please cite the publication as follows:

Inkinen, H., Kianto, A., Vanhala, M., Ritala, P. (2017). Structure of intellectual capital - an international comparison. Accounting, Auditing and Accountability Journal, vol. 30, issue 5. pp. 1160-1183. DOI: 10.1108/AAAJ-11-2015-2291

This is a parallel published version of an original publication. This version can differ from the original published article. 


\section{Structure of intellectual capital - An international comparison}

Accounting, Auditing \& Accountability Journal. Vol. 30 No. 5, 1160-1183.

\section{Author names and affiliations}

Author 1 Name: Henri Inkinen 1

Author 2 Name: Aino Kianto 1

Author 3 Name: Mika Vanhala

Author 4 Name: Paavo Ritala

1Lappeenranta University of Technology

School of Business and Management

P.O. Box, 53851 Lappeenranta, Finland

Corresponding author: Henri Inkinen

Corresponding Author's Email: henri.hussinki@lut.fi

\section{Abstract \\ Purpose}

Academics and practitioners around the world have shown interest in what constitutes the relevant intellectual capital (IC) in firms. However, studies have largely neglected to examine whether IC has identical or different structural elements in various parts of the world. This study draws on institutional theory and suggests that country-specific institutional structures may impact the perception of IC, and empirically analyses whether differences exist between five countries.

\section{Design/methodology/approach}

This study tests for the differences in the underlying categorizations of IC in a sample consisting of 708 firms across five countries. Confirmatory factor analysis and comparison of different possible IC models are conducted to empirically examine IC structure.

\section{Findings}

Results demonstrate that IC has predominantly the same underlying elements across the examined countries. However, trust capital in Finland and renewal capital in Serbia are structurally different compared to other countries.

\section{Research limitations/implications}

Institutional theory and multinational corporate superculture can explain the similarity in the IC structures across countries. Specifically, globalized markets carry institutionalized rules, norms, 
and expectations for the participating firms; under the influence of this superculture, the firms begin to assimilate. Conversely, the differences suggest that some country- and culture-specific differences remain even during the transition to global markets.

\section{Originality/value}

This study is among the first to question the assumption that IC has identical structural elements across the world, and merges theories of IC and institutions to explain possible origins of these differences.

Keywords: intellectual capital, intellectual capital accounting, structure, superculture Article classification: research paper 


\section{Introduction}

The vast majority of today's global wealth is based on intangible factors including firms' IC (Edvinsson and Malone, 1997; Ferreira and Hamilton, 2010; Hamilton, 2006; Petty and Guthrie, 2000). Therefore, intellectual capital (IC) is currently a subject of vivid discussion in the realms of academia, business practice, and government. Researchers have widely suggested that, in the current knowledge economy, firm performance accrues primarily from intangible assets, known as the IC of the firm (e.g. Bontis, 1998; Cabello-Medina et al., 2011; Chen et al., 2004; Edvinsson and Malone, 1997; Hsu and Sabherwal, 2012; Inkinen, 2015; Sveiby, 1997; Youndt et al., 2004). The concept of IC covers the intangible resources and capabilities that a company needs to function, compete, and create value (Brooking, 1996; Drucker, 1993; Edvinsson and Malone, 1997; Grant, 1996; Nahapiet and Ghoshal, 1998; Stewart, 1997; Sveiby, 1997).

To examine the role of knowledge and intangibles in producing organizational value and competitiveness, researchers in the field of management accounting have developed a perspective labelled IC accounting (ICA; e.g. Roslender and Fincham, 2001; Tayles et al., 2002; Ricceri, 2008; Guthrie et al., 2012; Dumay, 2014). This perspective focuses on identifying, measuring, and reporting knowledge resources as well as the activities that develop such resources, and aims to understand how a firm's IC can be managed and measured for the purpose of improved management control (e.g. Mouritsen et al., 2001; Bukh et al., 2005; Mouritsen and Larsen, 2005).

The ICA perspective has generated interest across the globe, spurring organizational development and academic research activities in a wide variety of countries. An examination of the literature concerning IC in firms in different countries revealed that many managerial-perspective IC studies are based on a theoretical framework that divides IC into three elements related with human, structural/organizational, and relational/social capital dimensions (e.g. Bontis, 1998; Edvinsson and Malone, 1997; Roos and Roos, 1997; Stewart, 1997; Sveiby, 1997). This three-dimensional categorization has been widely implemented in empirical studies concerning IC in firms across the world, from Malaysia and Taiwan to the US and Canada, as well as from Uganda, Jordan, and Turkey to Spain, Belgium, and Luxemburg (e.g. Bontis, 1998; Bontis et al., 2000; Bozbura, 2004; Youndt et al., 2004; Hsu and Fang, 2009; Sharabati et al., 2010; Hormiga et al., 2011; Kamukama et al., 2011; Mention and Bontis, 2013).

However, organization and management can differ in various national, regional, and cultural contexts, as demonstrated by the studies on cross-cultural management (Adler, 1991; Hofstede $e t$ al., 2010; Trompenaars, 1993) and comparative management accounting (Endenich et al., 2011; MacArthur, 2006). Because the widely applied tripartite model of IC dimensions (i.e. human, structural/organizational, and relational/social capital) was originally coined in the latter part of the 1990s in reference to firms in highly developed countries (e.g. Sweden, Canada), it is fair to assume that the key intangible assets that produce value for the organization may vary in different conditions. Nevertheless, researchers have applied the tripartite model and other universal IC conceptualizations (e.g. value added intellectual coefficient by Pulic, 2000; calculated intangible 
value by Stewart, 1997) around the world in a rather straightforward manner, without questioning their applicability under varying cultural contexts (Dumay, 2009).

In fact, IC research has typically been conducted on the assumption that IC as a phenomenon is rather identical across regional, national, and cultural contexts. Overall, the majority of IC research has involved firms in a single regional context, and studies comparing results from several contexts are very rare. As a result, several scholars have called for studies that investigate the cultural aspect of IC (Yang and Lin, 2009) and that adopt a cross-national approach (e.g. Cabrita and Bontis, 2008; Bontis et al., 2007; Delgado-Verde et al., 2011; Huang et al., 2007) in order to assess the generalizability of the existing theoretical positions. As previously noted, in single-country studies, the IC framework has typically been directly applied using a model originally built by Western researchers arising from highly developed countries. Very few empirical studies to date have addressed the issue of if and how the structure of IC of firms differs in different national contexts. This paper argues that the literature lacks in-depth understanding of the national, cultural, or regional differences of IC.

A country's formal institutions, which are mainly regulatory, political, and economic, are reflections of that country's culture (Inglehart and Baker, 2000). Culture, in turn, is a reflection of a socially constructed reality that is built upon informal institutions that are persistent systems, shared meanings, and collective understandings (North, 1990; Peng et al., 2008; Scott, 1995). Thus, as cultures differ between countries (Hofstede, 1980), these differences exist also at the institutional level. This study integrates institutional theory and IC theory by suggesting that country-specific institutionalized peculiarities may impact the perception of IC. In more detail, this study claims that managerially-assessed IC is a framework that eventually builds its meaning through a socially mediated constitution, which may vary from context to context because it is influenced by institutional peculiarities.

To address the question of whether the structure of IC is universal (as most existing studies implicitly assume) or varies across countries, this study empirically examines a managerial assessment of IC across firms with more than 100 employees in five countries. The study is based on a cross-country dataset that was collected between fall 2013 and spring 2014 during a research project that was conducted in co-operation with partner institutions from five countries. These countries span from developed (Finland, Spain, Italy) to developing countries (Russia, Serbia), as well as from collectivist (Russia, Serbia) to more individualistic cultures (Finland, Italy, Spain) (Hofstede et al., 2010; cf. Greif, 1994). First, this article suggests an extended and elaborated categorization of IC to better understand the differences between country contexts beyond the traditional tripartite distinction of IC. Then, it tests the differences in the underlying categorizations in a sample consisting of structured survey responses of 708 firms across five countries.

The results indicate that IC structure is mostly similar across the five countries, but some differences exist. This suggests that the managerial construction of IC is mostly a universal phenomenon, with specific, notable distinctions regarding the construction of trust capital in 
Finland and renewal capital in Serbia. These results provide interesting, institutionally-driven implications for ICA research, as well as for IC research more generally. The article concludes with a discussion of those findings and their implications for ICA research and practice.

The following section offers an overview of the relevant IC literature as well as a suggestion for a novel seven-dimensional conceptual model of IC. The section progresses by discussing crosscountry differences in the structure of IC through the lenses of an institutional approach. Following this discussion is a description of the data collection and methodological selections, with a focus on the survey research strategy. The final two sections present the results of the analysis and the conclusion with a discussion and an overview of the study's implications.

\section{Intellectual capital: literature review and new dimensions}

ICA research can be divided into two key approaches: the financial statement approach and the organizational approach (Guthrie et al., 2012). Whereas the first is interested in the conditions and solutions for external accounting and disclosure measures of intangibles, the latter focuses on organizing and managing intangibles. This paper adopts the second, organizational approach to IC, since it allows for the conceptual and empirical assessment of the detailed and potentially culturally-specific fabric of firm-level IC.

Within this literature, most studies have viewed IC as composed of three elements: human, structural/organizational, and relational/social capital (Bollen et al., 2005; Bontis, 1998; Bozbura, 2004; Edvinsson and Malone, 1997; Hormiga et al., 2011; Hsu and Fang, 2009; Sharabati et al., 2010; Tseng and Goo, 2005; see also Inkinen, 2015). More recently, some researchers have questioned whether these three elements are sufficient, or if there are some other intangible value drivers that are not addressed by this customary categorization of IC (e.g. Kaufmann and Schneider, 2004; Kianto, 2007). Specifically, past studies have distinguished the following three additional dimensions: entrepreneurial capital, renewal capital, and trust capital. Viewing intangibles from this broader, more detailed perspective might enable an improved identification of country-specific variations in the IC structures of firms. The first part of the theory-building section discusses these new IC elements and the reasons for including them in IC models. Then the study moves on to demonstrate what kinds of previous research on ICA have adopted a crosscountry perspective. The previous studies are quite limited, but still add to the understanding of the potential variation across countries in terms of the structure of IC.

\subsection{Towards an overarching IC typology}

Human, structural/organizational, and relational/social capital constitute the three-dimensional model of IC that has been established as an emergent standard within IC literature (Bollen et al., 2005; Bontis, 1998; Bozbura, 2004; Edvinsson and Malone, 1997; Hormiga et al., 2011; Hsu and Sabherwal, 2012; Hsu and Fang, 2009; Nahapiet and Ghoshal, 1998; Roos and Roos, 1997; Sharabati et al., 2010; Stewart, 1997; Subramanian and Youndt, 2005; Sullivan, 1998; Sveiby, 
1997; Tseng and Goo, 2005; Youndt et al., 2004). A recent systematic review of empirical IC literature by Inkinen (2015) reaffirmed that the three-dimensional IC measurement model has been far and away the most frequently used combination. Infrequently, researchers have included and examined some further IC dimensions, such as innovation capital (Chen et al., 2004; Maditinos et al., 2010; Tseng and Goo, 2005) and renewal capital (Kianto et al., 2010).

A multitude of elements constitute the IC dimensions. For instance, human capital refers to people and their thinking capability, skills, knowledge, experience, and motivation (Bontis, 1998; Edvinsson and Malone, 1997; Roos and Roos, 1997; Stewart, 1997), while structural/organizational capital includes "all the non-human storehouses" of knowledge within a firm (Bontis et al., 2000, p. 88), ranging from information systems, databases, and intellectual properties to culture-carrying artefacts of organization (Bontis, 1998; Edvinsson and Malone, 1997; Stewart, 1997). Finally, relational/social capital consists of the value and knowledge that reside in connections with customers, suppliers, distributors, partners, institutions, and various other related parties (Edvinsson and Malone, 1997; Nahapiet and Ghoshal, 1998; Roos and Roos, 1997).

One criticism of the three-dimensional model of IC is that it offers a rather rough categorization, as the amount and diversity of intellectual elements would permit a more accurate separation between the IC dimensions. Therefore, the categorization of IC into further dimensions, as depicted in Figure 1, enables a finer-grained analysis and improved understanding of the phenomenon. Actually, these additions do not expand the theorized boundaries of overall IC, but rather distinguish some of the dimensions into more specific elements, as they are the results of a critical examination of the established three-fold model. 


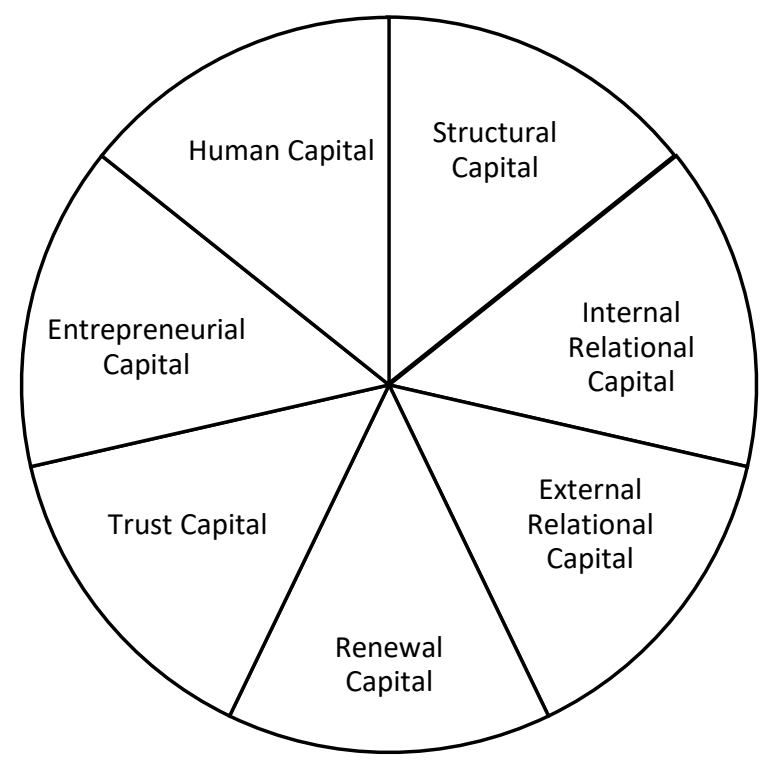

Figure 1: Intellectual capital dimensions: an elaborated model

Figure 1 shows that, in addition to the established human, structural/organizational, and relational/social capital dimensions, this study identifies a group of new elements to IC. First, this study separates the established dimension of relational capital into internal and external dimensions, since the earlier definitions have been conceptually inconsistent. The relational/social capital dimension of IC is usually related to either extra-organizational (e.g. Bozbura, 2004; Cabrita and Bontis, 2008), intra-organizational (Yang and Lin, 2009), or both intra- and extraorganizational (Yli-Renko et al., 2002) contexts. To make this difference explicit, this study divides the dimension into internal and external relational capital, referring to relationships with intra-organizational and extra-organizational stakeholders. The other expansions to the classic IC categorization include renewal, entrepreneurial, and trust capital. The following sub-sections discuss these dimensions.

\subsection{Renewal capital}

As organizational resources and capabilities related with knowledge distribution, leverage, organizational memory, and learning are especially important for firms' competitiveness (e.g. Zollo and Winter, 2002), it seems logical to separately address these issues. Thus, a categorization of IC should include renewal capital, which describes the organization's capacity to renew through knowledge-related activities, such as learning and creativity (e.g. Kianto et al., 2010). 
From a knowledge-based perspective, the key mechanisms of organizational renewal are learning (i.e. development of novel mental models and insights; see e.g. Fiol and Lyles, 1985; Huber, 1991) and knowledge creation (Nonaka and Takeuchi, 1995). Therefore, renewal capital refers to the organization's capacity to learn and to create new knowledge (Argyris, 2002; Nonaka and Takeuchi, 1995) through activities such as acquiring new information and developing new skills. It represents the resources of the firm for renewing what it knows and can do (Kianto et al., 2010). An organization with high renewal capital, sometimes also called innovation capital (Chen et al., 2004), is able to build on previous knowledge and to generate new knowledge (Maditinos et al., 2010), as well as to develop new products, services, and inventive ideas on a continuous basis (Tseng and Goo, 2005), and thus innovate. Also, an organization that is able to develop new knowledge, innovate, and learn is likely to respond in an agile manner to radical changes in the market and future challenges and to sustain its competitiveness even in changing conditions (Edvinsson and Malone, 1997).

As the discussion above indicates, some links exist between renewal capital and structural/organizational capital within the three-dimensional IC model. However, renewal capital should be studied separately from other structural capital issues because it explicitly addresses renewal through learning and knowledge creation, while structural/organizational capital handles strategies, cultural artefacts, databases, information systems, processes, manuals, patents, routines, mechanisms, charts, and other structural arrangements (Inkinen, 2015). Thus, the contents of these dimensions are not overlapping, and both are required to construct an overarching concept of IC.

\subsection{Entrepreneurial capital}

Whereas the discussion on renewal capital concerns the firm's ability to learn and to acquire new knowledge and skills, entrepreneurial capital is related to the entrepreneurial behaviour exerted by members of the organization. Entrepreneurial capital consists of the competence and commitment related to entrepreneurial activities within the firm (e.g. Erikson, 2002). It is the courage, initiative-taking, and pro-activeness that enable more self-determining development activities within the firm (Dess et al., 1997; Hughes and Morgan, 2007). Further, entrepreneurial capital is defined as the firm's pro-activeness with new opportunities to develop products and strategies and acquire signals from the market (Lumpkin and Dess, 1996), its risk-taking ability in terms of uncertainty acceptance and capitalization on market instability (Cesaroni et al., 2015; Lumpkin and Dess, 1996), its aggressive decision-making to outperform rivals (Lumpkin and Dess, 1996), and its empowerment of employees to make independent decisions, be creative, and be more self-directed (Hurley and Hult, 1998). Thus, a firm with strong entrepreneurial capital is likely to gain competitive advantages through its employees who have a strong affective commitment to the firm, are proactive, and are empowered to make quick decisions (Inkinen et al., 2014).

Entrepreneurial capital is nurtured by the general organizational climate; thus, a linkage exists between it and the structural/organizational capital dimension within the emergent standard three- 
dimensional IC model, even though previous IC studies have not typically discussed entrepreneurial orientation. However, it is important to introduce entrepreneurial capital as an independent dimension within the IC model, as its examination will increase the understanding on how entrepreneurial behaviour influences firm performance outcomes. As such, it carries important managerial implications on issues such as power decentralization and motivation.

\subsection{Trust capital}

An important intangible socio-cultural aspect in organizations is trust, which is an explicitly different issue from relationships in some cultures and more embedded in relationships in other cultures (Gold et al., 2002). To determine the potential institutional differences in this regard, a relationship-related trust capital is included in the IC categorization, which refers to the trait of trust that adds value to internal and external relationships (e.g. Mayer et al., 1995).

Trust is commonly defined as "a psychological state comprising the intention to accept vulnerability based upon positive expectations of the intentions or behaviour of another" (Rousseau et al., 1998, p. 395). Trust is an essential component of social capital, which enables knowledge sharing and creation across ties (Nahapiet and Ghoshal, 1998). Trust thereby facilitates intra- and inter-organizational knowledge flows, and potentially aids innovation and performance in doing so. Organizational trust is an attribute that has value to the organization, is rare, and is hard to imitate or replace; as such, it could be a source of sustainable competitive advantage (Barney and Hansen, 1994). In other words, organizational trust is a valuable intangible asset (see e.g. Barney, 1991; Gould-Williams, 2003; Tzafrir, 2005; Boxall and Purcell, 2011), and a high level of trust is a strategically important source of competitiveness (Barney, 1986). Consequently, trust between and within organizations could play a role in achieving sustainable competitive advantage through instilling attitudes and behaviours in a way that will eventually constitute a culture of trust that is unique and inimitable (cf. Boxall and Purcell, 2000). Moreover, trust cannot be easily transferred to other organizations because it is a product of historical development and therefore is difficult to imitate.

Although trust capital should be seen as an independent and distinct dimension of IC, it shares some interconnections with the three-dimensional IC conceptualization. First, trust is an integral part of the organizational climate and culture, so it touches partly on structural/relational capital (e.g. Nahapiet and Ghoshal, 1998; Anderson and Jack, 2002). Second, trust is embedded in an organization's relations and relationships, which makes it somehow an attribute of relational capital (e.g. Nahapiet and Ghoshal, 1998; Kale et al., 2000). Additionally, as stated in the previous paragraph, trust is also a component of social capital.

However, studying trust as an independent dimension and separately from another IC dimensions offers significant value as it tends to have a remarkable effect on the value of relationships. Thus far, the empirical IC literature has not considered trust as an independent IC dimension, so the level of understanding on how trust, as a part of IC, influences firm performance is very limited (for a recent review, see Inkinen, 2015). In sum, trust can be considered one form of a company's 
intangible resources and thus one type of IC asset. This article defines trust capital as the trust embedded in a company's internal and external relationships (e.g. Mayer et al., 1995).

\section{Cross-country differences in IC structure: institutional approach}

In addition to the novel categorization of IC, this study suggests that IC is a phenomenon that is impacted by the institutional context of activity, i.e. the structures and mechanisms of social order and co-operation (Scott, 1995). Regulatory, political, and economic institutions set the rules for organizations that operate within a country, shape how governments and individual members can establish or alter the formal institutions, and define monetary and fiscal policies (Holmes et al., 2013). In addition to these formal institutions, each country has also informal institutions, which are the systems, shared meanings, and collective understandings that formulate the socially constructed reality and reflect on a country's culture (North, 1990; Peng et al., 2008; Scott, 1995). Further, even though formal institutions are explicit and quite stable by nature, they persist only if the country's people collectively see them as meaningful and effective (Tolbert and Zucker, 1996). Therefore, formal institutions are embodiments of the country's people and culture (Inglehart and Baker, 2000).

Cultures make countries different (Hofstede, 1980), and the arguments above suggest that the differences exist also on the institutional level; thus, these institutionally-driven peculiarities are likely to have an effect on how IC is constructed in different countries. In particular, differences may emerge in how the managerial construction of IC assessment in terms of the seven IC dimensions constitutes the overall IC in a given country context. For instance, there might be differences of which particular IC dimensions are seen as separate from each other, and which are seen as belonging to the same socially constructed element of IC. Therefore, this study claims that managerially-assessed IC is a framework that eventually builds its meaning through socially mediated constitution, which may vary from one context to another because it is influenced by the institutional characteristics arising from the country's culture.

Previous studies have indicated variation within the levels of IC dimensions between countries (e.g. Lin and Edvinsson, 2008, 2011, 2012) and in IC reporting (e.g. Guthrie et al., 2004; Guthrie et al., 2006; Vandemaele et al., 2005), but no research has yet discussed the national differences in the underlying IC structures and configurations. While some researchers, such as Tovstiga and Tulugurova (2009), have suggested that the impact of IC on organizational performance is conditioned on the socio-political context of their operations, no studies have directly addressed the culturally bound versus universal nature of the underlying models of IC. This study agrees with Dumay (2009) that a drawback of IC research is the tendency for researchers to try to fit the tripartite model, which might in the end have little relevance for understanding value creation in varying country contexts. Distinguishing the national peculiarities of IC structures is important, as it affects the implications of the previously conducted cross-national comparative studies on IC. 
Also, the result of this study increase understanding on which IC dimensions should be measured and managed in different national contexts.

Whether the structure of IC differs in different country contexts has been left unexplored in the existing research. Comparative research on IC is rare, and most studies have examined IC within a single country, typically implementing some IC method that was originally developed in a different country context, with possibly a very different societal system, geographical attributes, and cultural factors. Notably, a large number of studies have implemented the tripartite division of IC into human, structural/organizational, and relational/social capital across all continents (e.g. Bontis, 1998; Bontis et al., 2000; Bozbura, 2004; Youndt et al., 2004; Hsu and Fang, 2009; Sharabati et al., 2010; Hormiga et al., 2011; Kamukama et al., 2011; Mention and Bontis, 2013). However, these studies have not examined the applicability of the underlying structure for analysing the companies' IC. As a result, the issue of whether the nature of intangibles differs in various countries has been left relatively in the shade.

Among the few researchers that have examined ICA from a comparative perspective, Chaminade and Johanson (2003) investigated the implementation of a European research and organizational development project in Spain and Sweden. They argued that adopting and applying IC ideology and management activities differ according to the national culture. Abeysekera (2007) compared the IC reporting of large firms operating in Sri Lanka and Australia, and found that the differences in the reporting of intangibles between firms in these two regions could be attributed to cultural values as well as economic, social, and political factors. Tovstiga and Tulugurova (2009) examined IC practices across four regions, and argued that differences between IC practices of firms reflect socio-economic and national cultural factors. Nazari et al. (2009) found significant differences in IC management and the organizational characteristics influencing it between Canada and the Middle East. Based on experiences of ICA implementation in Spain and Norway, Chaminade and Roberts (2003) suggested that successful strategies for ICA implementation are likely to differ in different countries. Guthrie et al. (2006) compared the voluntary reporting of IC in Australian and Hong Kong-based listed companies, and pointed out that, despite a lack of quantitative measures, Australian companies managed to disclose more information on IC. However, Bozzolan et al. (2006) investigated IC disclosure practices in Italy and the UK, and found that they did not differ across nations, but rather as a function of firm size and sector.

Based on this evidence concerning the impact of national culture on IC management activities, it seems plausible, from an institutional approach, that the structure of the IC phenomenon itself (i.e. the configuration of the intangibles perceived to create value for the firm in a particular context) would differ from country to country. For example, regulatory institutions set expectations for how entrepreneurial capital can create value within the firm, and political institutions, which influence the political stability of the country, are likely to affect how trust capital is perceived. The following section proceeds to an empirical examination of the institutionalization of IC, starting with describing the data collection and methods of the study. 


\section{Methods}

\subsection{Sample and data collection}

The data utilized for this study included five survey datasets using the same research design and items, but conducted in different countries. Survey data were collected from Finland, Italy, Russia, Serbia, and Spain in 2013-2014. These countries were selected based on international academic collaboration during a research project by five academic institutions from the countries. The aim of the project was to study IC with a rather diversified set of developed and emerging market countries. The questionnaires were developed in English and then translated into different languages. From each country, the initial population comprised a cross-industry sample of companies that included all firms with at least 100 employees. Country-specific databases (e.g. Intellia in Finland and SABI in Spain) were utilized in identifying companies. All eligible firms were contacted; for practical reasons, the method of contact varied slightly between countries. For example, an external research company contacted firms in Finland by telephone. In other countries, researchers conducted the data collection via telephone, face-to-face interviews, and online surveys. To reduce the possibility of bias resulting from these various data collection modes, all of the data collection procedures strictly followed the similar survey design format and data collection guidelines to minimize any variation in the respondents' assessment of the items. Furthermore, recent method literature has suggested that the mode of data collection does not matter in terms of reliability of the findings (see e.g. Hair et al., 2006; Maguire, 2009; Szolnoki and Hoffman, 2013; Dodou and de Winter, 2014). Based on this assessment, this study has no major risk of bias in terms of data collection modes across countries. Confidentiality was emphasized, and the respondents were promised a summary of the results.

Following the initial contacts, 708 usable responses were received from Finland (259), Spain (180), Italy (102), Russia (87), and Serbia (80). In all countries, the study followed the key informant approach in that most of the respondents held positions such as a human resources (HR) director or manager, other director or manager, or managing director, indicating their expertise and

key position regarding the issues regarding IC. In order to examine whether there were differences between different groups of respondents within each country, a one-way analysis of variance (ANOVA) comparison of means was performed for each individual item. No notable differences were found in how respondents with different positions evaluated the existence of IC dimensions.

The companies in the sample represented a wide variety of industries, including manufacturing, wholesale and retail trade, miscellaneous services, and transportation and storage. The next subsection discusses the characteristics of samples from different countries in more detail.

\subsection{Descriptive statistics}

In terms of age, some differences existed among the studied countries. The average age of the firms in the Finnish, Spanish, and Italian samples was around 30 years. The companies from Serbia 
and Russia were younger, around 20 years. The oldest companies were found in Spain (mean value 31 years) and the youngest in Russia (19 years). In all countries, most of the companies were established 11-50 years ago. It should be noted that the percentage of young companies (established 0-5 years ago) was low in the samples from Serbia (0\%), Spain (0.6\%), Italy (2.9\%), and Russia (4.9\%).

The company size was assessed by two means; by the number of employees and the volume of annual sales. In the Spanish (65.7\%), Finnish (53.7\%), and Italian (47.5\%) samples, most of the companies had 100-249 employees, whereas Russian (50.6\%) companies employed more than 1000 people. This discrepancy is shown also in the mean values for employees, as the average Russian company had about 7000 employees, whereas Spanish and Finnish companies employed an average of 337 and 446 people, respectively. Utilizing the annual sales metric, this study found that quite large variations existed between countries. The biggest average sales figures were found in Italy ( 820 million euros) and in Russia (627 million euros). The smallest companies in terms of sales were Spanish (92 million euros) and Serbian (98 million euros). Finnish companies were positioned in between, with average sales of 157 million euros.

Table 1 presents the four biggest industries of the sample from each country. In most of the countries, manufacturing was the biggest industry among the studied companies. The percentage varied from Serbia's 50\% to Italy's 34\%. Only in Russia was wholesale and retail trade (22.4\%) represented more than manufacturing (20\%). Other industries that were among the four biggest in most of the countries were services (Finland, Russia, and Serbia) and information and communication (Italy, Russia, Serbia, and Spain). 
Table 1. Descriptive statistics.

\begin{tabular}{|c|c|c|c|c|c|}
\hline & Finland & Spain & Serbia & Russia & Italy \\
\hline $\mathrm{N}$ & 259 & 180 & 80 & 87 & 102 \\
\hline $\begin{array}{l}\text { Age (mean; } \\
\text { sd) }\end{array}$ & $28.5 ; 25.09$ & $31 ; 22.1$ & $21.24 ; 13.14$ & $18.99 ; 14.09$ & $28.9 ; 21.28$ \\
\hline $\begin{array}{l}\text { Personnel } \\
\text { (mean; sd) }\end{array}$ & $445.53 ; 734.44$ & $336.92 ; 542.17$ & $761.85 ; 1243.6$ & $7037.1 ; 23192.4$ & $\begin{array}{l}2411.15 \\
13928.40\end{array}$ \\
\hline $\begin{array}{l}\text { Sales 1000 } \\
\text { eur (mean; } \\
\quad s d)\end{array}$ & $156775 ; 400034$ & 92017.99; 230594 & $\begin{array}{c}97667 ; \\
128329.31 \\
\end{array}$ & $\begin{array}{l}627205 \\
1556125\end{array}$ & $\begin{array}{l}\text { 819755.44; } \\
\text { 4844279.27 }\end{array}$ \\
\hline \multicolumn{6}{|l|}{ Age (\%): } \\
\hline $0-5$ years & 8.5 & 0.6 & 0 & 4.9 & 2.9 \\
\hline $6-10$ years & 11.2 & 5 & 13.8 & 20.7 & 8.8 \\
\hline 11-50 years & 66.4 & 83.3 & 80 & 69.5 & 73.5 \\
\hline $50+$ years & 13.9 & 11.1 & 6.3 & 4.9 & 14.7 \\
\hline \multicolumn{6}{|l|}{$\begin{array}{l}\text { Personnel } \\
(\%):\end{array}$} \\
\hline $100-249$ & 53.7 & 65.7 & 34.7 & 22.4 & 47.5 \\
\hline $250-499$ & 23 & 22.5 & 26.7 & 20 & 18.8 \\
\hline $500-999$ & 10.7 & 8.4 & 18.7 & 7.1 & 12.9 \\
\hline $1000+$ & 9.4 & 3.4 & 20 & 50.6 & 20.8 \\
\hline \multicolumn{6}{|l|}{$\begin{array}{c}\text { Industry } \\
(\%):\end{array}$} \\
\hline Largest & $\begin{array}{c}\text { Manufacturing } \\
(37.8)\end{array}$ & $\begin{array}{c}\text { Manufacturing } \\
(43.9)\end{array}$ & $\begin{array}{l}\text { Manufacturing } \\
(50)\end{array}$ & $\begin{array}{l}\text { Wholesale and } \\
\text { retail trade } \\
(22.4)\end{array}$ & $\begin{array}{c}\text { Manufacturing } \\
\text { (34) }\end{array}$ \\
\hline $2^{\text {nd }}$ largest & Services (9.7) & $\begin{array}{l}\text { Information and } \\
\text { communication } \\
(28.3)\end{array}$ & $\begin{array}{c}\text { Wholesale and } \\
\text { retail trade } \\
(13.8)\end{array}$ & $\begin{array}{c}\text { Manufacturing } \\
(20)\end{array}$ & $\begin{array}{l}\text { Wholesale and } \\
\text { retail trade (16) }\end{array}$ \\
\hline $3^{\text {rd }}$ largest & $\begin{array}{c}\text { Transportation } \\
\text { and storage (8.1) }\end{array}$ & Other (8.3) & Services (11.3) & $\begin{array}{c}\text { Information and } \\
\text { communication } \\
(15.3)\end{array}$ & $\begin{array}{l}\text { Administrative } \\
\text { and support } \\
\text { service activities } \\
\text { (9) }\end{array}$ \\
\hline $4^{\text {th }}$ largest & $\begin{array}{c}\text { Administrative } \\
\text { and support } \\
\text { service activities } \\
(7.7) \\
\end{array}$ & $\begin{array}{l}\text { Professional. } \\
\text { scientific and } \\
\text { technical } \\
\text { activities (7.8) }\end{array}$ & $\begin{array}{c}\text { Information and } \\
\text { communication } \\
(7.5)\end{array}$ & Services (14.1) & $\begin{array}{l}\text { Information and } \\
\text { communication } \\
(9)\end{array}$ \\
\hline
\end{tabular}

\subsection{Measurement scales}

The survey consisted of 28 items measuring seven different dimensions for and representing together the concept of IC. In all scales, respondents were asked to assess how the different statements on IC dimensions applied to the organization they represented.

Because the comprehensive concept of IC is in its early stages, established measurement scales do not exist. Therefore, the measures for IC dimensions were both adapted from the previous literature and developed by the authors. First, a thorough literature review was conducted to find empirically 
validated measurement scales for IC. Then, the applicable scales were supplemented with items and scales developed by the authors. In order to confirm the operational validity and psychometric robustness of the scales attained, the survey was pre-tested by means of statistical analyses with the sample of managers $(\mathrm{N}=151)$ collected from Finnish companies. In addition, to ascertain content validity of the scales, an international panel of experts assessed the scales and gave their insights for further development. Their feedback was incorporated into the final version of the survey.

Appendix 1 presents the scales, items, and related literature sources for the different dimensions of IC. All of the measures were based on a five-point Likert scale (1-strongly disagree, 5-strongly agree).

\section{Results}

\subsection{The structure of intellectual capital}

As the comprehensive conceptualization of IC introduced in this study is quite novel, several analyses were performed to test whether the suggested structure for the IC dimensions exists universally in all countries and, if not, to determine what differences exist between countries. Thus, the objective of the following section is to test the validity and applicability of the proposed conceptual model of IC in different countries, and to identify the similarities or possible differences in the structure (different dimensions) of IC between countries.

Confirmatory factor analysis (CFA) was conducted to test the dimensionality of the structure for the concept of IC dimensions. According to the theoretical conceptualization, the structure of IC should exhibit a latent structure with seven factors. A total of 708 cases were processed by means of LISREL 8.50. PRELIS 2.50 was used to compute the covariance matrix, and the maximum likelihood estimation method was applied. The analyses were conducted separately for the datasets from each country.

First, CFA was conducted separately for each factor (i.e. each IC dimension separately) to verify that the items were, in fact, grouped together. During this phase, a few items were removed (one item at a time) because of the large standardized residuals with the other items.

In the next phase, all seven factors were tested together. In the analysis for all samples, the initial model fit indices indicated that the original model needed to be re-specified to fit better with the sample data. Then items were gradually removed according to the values of the standardized residuals. From each pair of items with a large standardized residual, the one with a lower squared multiple correlation was removed and the one resulting in greater improvement in the model fit was retained. As a result of the above steps, several items were removed. The lowest number of items removed was from the Finnish data (6 items) and the highest from the Serbian data (16 items). 
Appendix 1 presents the final models and model fit indices for the structure of IC in different countries. The following three absolute-fit measures were obtained: the likelihood-ratio chi-square value, the root mean square error of approximation (RMSEA), and the goodness-of-fit index (GFI). Even though all the measures fell within acceptable levels, incremental measures i.e. the nonnormed fit index (NNFI), the comparative fit index (CFI), and incremental fit index (IFI) were needed to ensure acceptability of the models from other perspectives.

In sum, the various measures of overall goodness-of-fit gave sufficient support to deem the results an acceptable representation of the hypothesized construct (see Appendix 1). The cross-validation (see e.g. Hair et al., 2006; Conroy and Motl, 2003) revealed that there are differences in how IC is perceived to exist in various countries. In the Finnish sample, all seven hypothesized dimensions remained, while at the opposite extreme the Serbian sample retained only five dimensions. The most significant findings were that trust capital was found as a dimension of IC only in the Finnish sample, and renewal capital did not differentiate as a dimension of its own in the Serbian sample. These findings will be further elaborated in the discussion section.

In addition, some observations can be made regarding item-level consistency between countries in terms of the retained IC dimensions. In general, in all countries where a specific IC dimension existed, the structures were alike. For example, both external relational capital and entrepreneurial capital were evaluated with three items that seemed to work in all countries. Also in internal relational capital, structural capital, human capital, and renewal capital, the structures were, if not alike, at least quite consistent between different countries. Only a few one-item differences were observed.

The structure of IC may be different than suggested in this study. For example, one could claim that there are no distinct dimensions of IC (i.e. IC can be conceptualized as a one-dimensional construct), or that the relationship-related dimensions (i.e. internal and external relational capital) should not be examined separately as suggested here. Thus, in order to further establish the dimensionality and validity of the suggested novel structure of IC, the study compared the initial model with competing models. The developed model outperformed competing models on all model fit indices, providing additional support for the chosen model.

\subsection{Construct reliability and validity}

\section{Reliability}

The reliability of the items was evaluated by their path coefficients and squared multiple correlations (R2). Composite reliability (CR; also known as construct reliability) was used to assess the reliability of each factor. A complementary measure is the average variance extracted (AVE), which directly shows the amount of variance that is captured by the construct in relation to the amount of variance due to measurement error. 
Appendix 1 shows the reliability statistics. All the items were significantly related to their specified constructs, verifying the posited relationships among the indicators and constructs. The CR ranged from 0.63 (for structural capital in the Finnish sample) to 0.89 (for external relational capital in the Italian sample), all exceeding the minimum recommended level of 0.60. The AVE reached the recommended 50\% (cf. Diamantopoulos and Siguaw, 2000; Hair et al., 2006) in all but two factors, which were structural capital and trust capital in the Finnish sample. In addition, the squared multiple correlations were also mainly over or near the limit of 0.50 .

\section{Convergent validity}

According to Bagozzi and Yi (1991), weak evidence of convergent validity results when the factor loading on an item of interest is significant. Strong evidence is achieved when the squared factor loading is greater than 0.5 (i.e. more than half of the total variation in the measures is due to the trait). Secondly, convergent validity can be assessed in terms of the degree to which the factors (which could be considered different measures of the construct) are correlated (Bagozzi and Yi, 1991; Smith et al., 1996).

As shown in Appendix 1, for most of the items, loadings were greater than 0.7 (the lowest loading was 0.518 ), and all loadings were statistically significant at the 0.01 significance level. In addition, most of the items turned out to have a squared factor loading (R2) greater than 0.5 . Table 2 gives more evidence of convergent validity in that the correlations between the dimensions of IC stocks were all significant, ranging from 0.165 to 0.691 . This suggests that the components all measured some aspect of the same construct.

Table 2. Correlation matrix.

\begin{tabular}{|l|c|c|c|c|c|c|c|}
\hline & Mean & 1 & 2 & 3 & 4 & 5 & 6 \\
\hline 1. Internal relational capital & $3.43-4.06$ & & & & & & \\
\hline 2. External relational capital & $3.38-4.07$ & $0.328-0.481$ & & & & & \\
\hline 3. Structural capital & $3.58-4.25$ & $0.371-0.552$ & $0.275-0.531$ & & & & \\
\hline 4. Human capital & $3.69-4.05$ & $0.165-0.691$ & $0.218-0.480$ & $0.324-0.586$ & & & \\
\hline 5. Renewal capital & $3.41-3.72$ & $0.344-0.501$ & $0.364-0.529$ & $0.335-0.504$ & $0.371-0.600$ & & \\
\hline 6. Trust capital & 3.94 & 0.484 & 0.477 & 0.384 & 0.576 & 0.572 & \\
\hline 7. Entrepreneurial capital & $3.10-3.65$ & $0.275-0.538$ & $0.322-0.478$ & $0.316-0.517$ & $0.334-0.643$ & $0.498-0.646$ & 0.444 \\
\hline
\end{tabular}

Note: All samples are included in the table (i.e. the lowest and highest values are presented). All correlations are significant at least at the 0.05 level (2-tailed).

\section{Discriminant validity}

The discriminant validity was evaluated by two methods. The first method assessed whether the AVE was greater than the variance shared between that construct and the other constructs in the model (i.e. the squared correlation between two constructs; Fornell and Larcker, 1981). Almost all constructs for all countries of the study fulfilled this condition. In all samples, the model's AVEs were greater than the squared correlation between constructs. In addition, the discriminant validity was evaluated with the method recommended by Anderson and Gerbing (1988). Two models were 
compared for each possible pair of constructs. In the first model, constructs were allowed to correlate freely, and in the second model, the correlations were fixed as equal to one. All chisquare difference tests in all samples were significant, which indicates that all pairs of constructs correlated at less than one. In sum, these two tests offer evidence of a sufficient level of discriminant validity.

\section{Discussion and implications}

IC and ICA researchers have long traditions of measuring the value of firm-specific intangible assets across the world, with an (often implicit) assumption that the phenomenon is universally similar. However, the variations of institutional settings across countries affect how people and organizations think and behave. Consequently, perceptions of IC can be strongly impacted by context-specific institutional features. To provide more evidence on the research gap in cultureand context-specificity of IC, this paper examined whether the structure of IC is universal across its different dimensions, or whether it varies in firms that represent different countries and cultural backgrounds. Empirical data for this study was collected from firms in five countries with unified translated versions of a structured survey, and the national IC structures were analysed via statistical methods. The data were collected from directors and managers who were dealing with practical management of IC; thus, this study captured novel understanding of which IC dimensions conceptually exist in the five surveyed countries by building on these expert views on IC issues.

Contrary to the expectations, the results indicated surprisingly few differences in terms of the perceived IC structures among the firms in the five countries. In fact, the structure of IC was very similar across the countries, and the posited country- and culture-specific institutional differences (Hofstede et al., 2010) did not translate as differences in how the managers in different countries perceived the structure of IC. Thus, this finding substantiates Tovstiga and Tulugurova's (2009) observation that key intangible assets differed more across firms than across regions. Further, this finding points out the impact of a multinational corporate superculture that is carried by globalized markets and preserved and adjusted by the firms that operate within the same markets. This superculture stretches across country borders and is somewhat apart from local systems and interplay (Munch, 1964). The superculture sets rules, norms, and expectations for the firms that operate under its influence. For instance, it sets minimum requirements for employee skills and characteristics and therefore increases demand for certain types of human capital across country borders. Also, it irreversibly alters the meaning of relationships, as the firms switch from a local perspective to a global mind-set. Possibilities in information storage, analysis, and leverage of knowledge through information technology have become available for firms across the globe. In the point of view of for-profit firms, the globalized and digitalized markets and the associated supercultures seem to be more powerful influencers in terms of behaviour and worldview than the domestic institutions. In sum, as the firms are situated in an institutional environment characterized by a multinational corporate superculture, they will adjust to that institutionalized reality by 
adopting the prevailing practices, which explains why the firms around the world assimilate and also perceive IC in a similar fashion (see Chuang et al., 2011).

Despite the overall similarities, the data analysis pointed out some interesting differences between countries regarding the managerial perceptions of IC structures. Notably, the facet of trust capital was analysed to be an independent IC dimension solely within the Finnish companies, and could be therefore claimed to be a completely Finnish phenomenon. This finding indicates that Finnish companies and business managers do not necessarily require existing long-term relationships to trust another party. Instead, they trust as a default, emphasizing that trust is an institutionalized norm within the Finnish culture (see Scott, 1995). This relates with the recent discussions in Finnish politics and media, identifying Finland as a high-trust society (Korhonen and Seppälä, 2005). In comparison, trust capital was embedded into other IC dimensions in other studied countries. Typically, trust is a product of long-term relationships (e.g. Cropanzano and Mitchell, 2005) and thus tied to relational capital dimensions (e.g. Nahapiet and Ghoshal, 1998).

Another notable exception was that the independent managerial construct of renewal capital was missing in the Serbian context. This discrepancy might be due to the country's gradual transition to the free economy, which is still ongoing and increases managers' tendency to avoid uncertain situations such as renewal issues (Hofstede et al., 2010). However, this finding must be retained for further interpretation in future research because some other cultures had relatively high uncertainty avoidance within the country samples wherein renewal capital appeared as an independent structure (Spain, Italy).

On the other hand, the results can be contrasted with previous studies demonstrating differences among nations in terms of how firms manage IC. For instance, Guthrie et al. (2006), Abeysekera (2007), Tovstiga and Tulugurova (2009), and Vandemaele et al. (2005) found differences in the reporting of intangibles between firms in various countries. Also, previous studies have proposed that the adoption of an IC perspective and effective ways to apply IC management practices differ at least between some countries (Chaminade and Johanson, 2003; Chaminade and Roberts, 2003; Nazari et al., 2009). However, the findings of this paper did not support these assertions; indeed, the findings suggested that management of IC may in fact become more uniform over time, as managerial perceptions of IC impact their behaviour and practices (Tayles et al., 2007).

\subsection{Implications for theory}

Whether the structure of the IC phenomenon differs across country contexts has been left unexplored in the previous research. Researchers have offered relatively few country-specific conceptualizations of IC, as most studies have taken a universal approach with very little concern for context-dependent factors. The findings of the current study demonstrated that applying the "universal" perspective in relation to IC issues has not been a completely unjustified approach. Overall, the findings pointed out that the phenomenon of IC seemed to possess rather similar structures in the studied countries. This finding also validated that the previously published 
literature on cross-country comparisons of IC have demonstrated solid foundations; therefore, IC researchers are encouraged to continue utilizing the universal approach.

The few country-specific peculiarities that were found in the IC structures highlighted that some cultural elements were institutionalized so deep within the nation that they shone through, even though the firms have gone international and been adopted into the superculture. These peculiarities were the society of trust in Finland and the non-existent concept of renewal capital in Serbia. Therefore, these findings suggested that some country-specific characteristics should be considered before utilizing the same theoretical foundations in several countries or conducting cross-country comparisons.

Overall, the ICA research community has recently begun calling for more localized explanations and approaches (Dumay, 2012; Dumay and Garanina, 2013) to increase the practical applicability and relevance of the field. These findings demonstrated that, even amid varying national settings, the key aspects of IC offer a noteworthy homogeneity across firms and contexts.

The findings also supported the usability of an amended categorization of IC, including the facets of renewal capital and entrepreneurial capital. These two issues should be especially relevant intangibles in the increasingly dynamic globalized business environments. Their existence in all of the examined countries (with the exception of renewal capital in Serbia) indicated that the tripartite conventional IC classification (e.g. Bontis, 1998; Edvinsson and Malone, 1997; Roos and Roos, 1997; Stewart, 1997) should be modified to include these aspects as well (as suggested by Inkinen et al., 2014).

Finally, building on institutional theory, various cross-country differences were expected to arise, mostly because of the different cultures and their roles as the basis to the country-specific institutions (Hofstede et al., 2010; Inglehart and Baker, 2000; North, 1990; Peng et al., 2008; Scott, 1995). However, this study uncovered universal premises of IC, suggesting that the multinational corporate superculture is a much stronger influencer than the local institutions. It seems that the firms from five rather different countries are assimilating as they operate within the same markets and are influenced by the same superculture. This finding appeared in the similar dimensionality of IC categories emerging from managerial construction in the sample countries. The differences also showed that some national institutions are so strong that they are able to affect and make a difference in the managerial construction of IC in some countries.

\subsection{Implications for practice}

As Mouritsen and Larsen (2005) proposed, knowledge resources can be made more manageable by making information on IC available. In particular, the seven-tier categorization of IC as discussed in this study (ref. Figure 1) provides managers with an illustration of the value-creating intangible resources of the firm, which then further supports their measurement and management. Through better understanding of the various IC dimensions, managers are capable of recognizing 
the core sources of value-creation potential, and of better allocating investments to identified gaps or spearheads.

The results of this study showed that, for the most part, IC can be perceived as a universally similar phenomenon in the studied five countries. Managers can use this information to evaluate the intangible value of firms, businesses, and markets in various types of situations where wide IC measurement applicability is useful. These situations include providing complementary analytical approaches for matters such as international company mergers and acquisitions, negotiations on strategic collaboration and alliances, and expansion of business functions to abroad. The measurements could also be utilized within multinational companies to assess the IC across different country offices and divisions. However, this study also uncovered institutionallyembedded, cultural peculiarities. As such, IC measurement and management programmes in various types of companies in different countries could adopt the measurement models examined in our study, while keeping in mind the organizational and cultural specificities.

The most striking country-specific peculiarity of IC was found regarding trust capital, which was highlighted as an independent construct only in the Finnish sample. When viewed through institutional theory, this finding implied that managers in Finland should take a contextual, cultural-oriented approach with regard to IC. While trust is a default trait of new or established relationships in Finland, it does not mean that the firm's international counterparts think and feel alike. Instead, it might take a long period of time to build a trustworthy relationship and achieve fruitful co-operation with international colleagues from a Finnish standpoint where trust is more profoundly embedded in organizational life.

The absence of an independent renewal capital construct in Serbia might indicate that economies in transition are characterized with such a high tempo of overall renewal that it affects also the managerial perception of it. Where managers in post-industrial economies are able to identify renewal capital (sometimes labelled as innovation capital) as a particular ability of a firm, their Serbian and other transition economy counterparts are so heavily involved with renewal issues that they cannot structurally separate it from other valuable resources or value-creating activities. Therefore, the Serbian managers could benefit from a more pragmatic approach on renewal, in order to improve the control and systematic management of IC in the midst of economic turmoil. This may apply to managing firms in other transition economy countries as well.

\subsection{Limitations and further research directions}

There are some limitations that are related to the research design and the execution of some of the country samples. Concerning Russia, the data covered mainly a small sub-set of firms from a particular region of Leningrad Oblast. Furthermore, there was variance in survey data collection modes between countries (e.g. telephone interviews, online survey). While previous research has offered arguments and evidence suggesting that such variation should not typically risk the reliability of the findings (e.g. Hair et al., 2006; Maguire, 2009; Szolnoki and Hoffman, 2013; 
Dodou and de Winter, 2014), future studies should seek to standardize the data collection procedures in terms of the data collection mode.

Furthermore, while authoritative voices such as Mouritsen (2006) and Guthrie et al. (2012) have made strong arguments in favour of adopting a performative rather than ostensive approach to IC in management accounting, this study notably took the ostensive approach. This approach was selected for gaining a wider perspective on the structure of IC in a wider set of firms in several countries. Naturally, this approach can and even should be complemented by performative research, offering contextual idiosyncratic understanding of how IC has been and is applied in particular firms across different nations. Obviously, implementing IC assessment methods alone does not suffice; however, to improve performance in the knowledge economy, these should be mobilized through storytelling and vivid communication of and around the measurement (Catasús et al., 2007).

Further research could build on our results in several ways. First, researchers could test the sevenpart categorization of IC further in different countries to see whether the sufficient universality holds in those settings as well. Second, future studies could connect managerial perceptions of IC dimensions to more objective indicators, to see whether there is a gap between perceptions and more concrete measurement approaches. Third, renewal capital in the Serbian context should be studied further, in order to understand what makes it different from the other countries. Doing so could produce generalizable insights into why the concept of firm-level renewal has such special features among rather young nations. Fourth, the managers in various countries should be interviewed on their stance towards and perception of IC, in order to pick up the potential underlying peculiarities and to compose localized research instruments for future studies.

\section{References}

Abeysekera, I. (2007), "Intellectual capital reporting between a developing and developed nation", Journal of Intellectual Capital, Vol. 8 No. 2, pp. 329-45.

Adler, N.J. (1991), International Dimensions of Organizational Behavior, 2nd ed., PWS-KENT, Boston.

Anderson, A.R. and Jack, S.L. (2002), "The articulation of social capital in entrepreneurial networks: a glue or a lubricant?”, Entrepreneurship \& Regional Development, Vol. 14 No. 3, pp. 193-210.

Anderson, J.C. and Gerbing, D.W. (1988), "Structural equation modeling in practice: a review and recommended two-step approach”, Psychological Bulletin, Vol. 103 No. 3, pp. 411-23.

Argyris, C. (2002), "Double-loop learning, teaching, and research", Academy of Management Learning \& Education, Vol. 1 No. 2, pp. 206-18. 
Bagozzi, R.P. and Yi, Y. (1991), "Multitrait-multimethod matrices in consumer research", Journal of Consumer Research, Vol. 17 No. 4, pp. 426-39.

Barney, J.B. (1986), "Organizational culture: can it be a source of sustained competitive advantage?", Academy of Management Review, Vol. 11 No. 3, pp. 656-65.

Barney, J.B. (1991), "Firm resources and sustained competitive advantage", Journal of Management, Vol. 17 No. 1, pp. 99-120.

Barney, J.B. and Hansen, M.H. (1994), "Trustworthiness as a source of competitive advantage”, Strategic Management Journal, Vol. 15 No. S1, pp. 175-90.

Bollen, L., Vergauwen, P. and Schnieders, S. (2005), "Linking intellectual capital and intellectual property to company performance”, Management Decision, Vol. 43 No. 9, pp. 1161-85.

Bontis, N. (1998), "Intellectual capital: an exploratory study that develops measures and models", Management Decision, Vol. 36 No. 2, pp. 63-76.

Bontis, N., Keow, W.C.C. and Richardson, S. (2000), "Intellectual capital and business performance in Malaysian industries", Journal of Intellectual Capital, Vol. 1 No. 1, pp. 85-100.

Bontis, N., Seleim, A. and Ashour, A. (2007), "Human capital and organizational performance: a study of Egyptian software companies”, Management Decision, Vol. 45 No. 4, pp. 789-801.

Boxall, P. and Purcell, J. (2000), "Strategic human resource management: where have we come from and where should we be going?", International Journal of Management Reviews, Vol. 2 No. 2, pp. 183-203.

Boxall, P. and Purcell, J. (2011), Strategy and Human Resource Management, 3rd ed., Palgrave Macmillan, Houndmills, UK.

Bozbura, F.T. (2004), "Measurement and application of intellectual capital in Turkey", The Learning Organization, Vol. 11 No. 4, pp. 357-67.

Bozzolan, S., O’Regan, P. and Ricceri, F. (2006), "Intellectual capital disclosure. A comparison of Italy and the UK", Journal of Human Resource Costing \& Accounting, Vol. 10 No. 2, pp. 92113.

Brooking, A. (1996), Intellectual Capital: Core Asset for the Third Millennium Enterprise, International Thomson Business Press, New York, NY.

Bukh, P., Nielsen, C., Gormsen, P. and Mouritsen, J. (2005), "Disclosure of information on intellectual capital in Danish IPO prospectuses", Accounting, Auditing \& Accountability Journal, Vol. 18 No. 6, pp. 713-32. 
Cabello-Medina, C., López-Cabrales, A. and Valle-Cabrera, R. (2011), "Leveraging the innovative performance of human capital through HRM and social capital in Spanish firms", International Journal of Human Resource Management, Vol. 22 No. 4, pp. 807-28.

Cabrita, M.R. and Bontis, N. (2008), "Intellectual capital and business performance in the Portuguese banking industry", International Journal of Technology Management, Vol. 43 No. 13, pp. 212-37.

Catasús, B., Ersson, S., Gröjer, J.E., and Yang Wallentin, F. (2007), "What gets measured gets... on indicating, mobilizing and acting", Accounting, Auditing \& Accountability Journal, Vol. 20 No. 4, pp. 505-21.

Cesaroni, F.M., Del Baldo, M., Demartini, P. and Paoloni, P. (2015), "Entrepreneurial, renewal and trust capital of Italian firms: insights from an empirical study", International Journal of Management, Knowledge and Learning, Vol. 4 No. 1, pp. 69-89.

Chaminade, C. and Johanson, U. (2003), "Can guidelines for intellectual capital management and reporting be considered without addressing cultural differences?", Journal of Intellectual Capital, Vol. 4 No. 4, pp. 528-42.

Chaminade, C. and Roberts, H. (2003), "What it means is what it does: a comparative analysis of implementing intellectual capital in Norway and Spain", European Accounting Review, Vol. 12 No. 4, pp. 733-51.

Chen, J., Zhu, Z. and Hong, Y.X. (2004), "Measuring intellectual capital: a new model and empirical study”, Journal of Intellectual Capital, Vol. 5 No. 1, pp. 195-212.

Chuang, Y.T., Church, R. and Ophir, R. (2011), "Taking sides: the interactive influences of institutional mechanisms on the adoption of same-sex partner health benefits by Fortune 500 corporations, 1990-2003", Organization Science, Vol. 22 No. 1, pp. 190-209.

Conroy, D.E. and Motl, R.W. (2003), "Modification, cross-validation, invariance, and latent mean structure of the self-presentation in exercise questionnaire", Measurement in Physical Education and Exercise Science, Vol. 7 No. 1, pp. 1-18.

Cropanzano, R. and Mitchell, M.S. (2005), "Social exchange theory: an interdisciplinary review", Journal of Management, Vol. 31 No. 6, pp. 874-900.

Delgado-Verde, M., Navas-López, J.E., Cruz-González, J. and Amores-Salvadó, J. (2011), "Radical innovation from relations-based knowledge: empirical evidence in Spanish technologyintensive firms", Journal of Knowledge Management, Vol. 15 No. 5, pp. 722-37.

Dess, G.G., Lumpkin, G.T. and Covin, J.G. (1997), "Entrepreneurial strategy making and firm performance: tests of contingency and configurational models", Strategic Management Journal, Vol. 18 No. 9, pp. 677-95. 
Diamantopoulos, A. and Siguaw, J. A. (2000), Introducing LISREL: A Guide for the Uninitiated, SAGE Publications, London, UK.

Dodou, D. and de Winter, J.C.F. (2014), "Social desirability is the same in offline, online and paper surveys: A meta-analysis", Computers in Human Behavior, Vol. 36, pp. 487-95.

Drucker, P.F. (1993), “The rise of the knowledge society”, Wilson Quarterly, Vol. 17 No. 2, pp. 52-70.

Dumay, J.C. (2009), “Intellectual capital measurement: a critical approach”, Journal of Intellectual Capital, Vol. 10 No. 2, pp. 190-210.

Dumay, J.C. (2012), "Grand theories as barriers to using IC concepts", Journal of Intellectual Capital, Vol. 13 No. 1, pp. 4-15.

Dumay, J.C. (2014), "Reflections on interdisciplinary accounting research: the state of the art of intellectual capital", Accounting, Auditing \& Accountability Journal, Vol. 27 No. 8, pp. 1257-64.

Dumay, J.C. and Garanina, T. (2013), "Intellectual capital research: a critical examination of the third stage", Journal of Intellectual Capital, Vol. 14 No. 1, pp. 10-25.

Edvinsson, L. and Malone, M. (1997), Intellectual Capital: Realising Your Company's True Value by Finding Its Hidden Brainpower, Harper Collins, New York, NY.

Endenich, C., Brandau, M. and Hoffjan, A. (2011), "Two decades of research on comparative management accounting - achievements and future directions", Australian Accounting Review, Vol. 59 No. 21, pp. 365-82.

Erikson, T. (2002), "Entrepreneurial capital: the emerging venture's most important asset and competitive advantage", Journal of Business Venturing, Vol. 17 No. 3, pp. 275-90.

Ferreira, S. and Hamilton, K. (2010), Comprehensive Wealth, Intangible Capital, and Development, World Bank Policy Research Working Paper No. 5452.

Fiol, M.C. and Lyles, M.A. (1985), “Organizational learning”, Academy of Management Review, Vol. 10 No. 4, pp. 803-13.

Fornell, C. and Larcker, D.F. (1981), "Evaluating structural equation models with unobservable variables and measurement error", Journal of Marketing Research, Vol. 18 No. 1, pp. 39-50.

García-Morales, V. and Llorens-Montes, F. (2006), "Antecedents and consequences of organizational innovation and organizational learning in entrepreneurship", Industrial Management \& Data Systems, Vol. 106 No. 1, pp. 21-42.

Gold, T., Guthrie, D. and Wank, D. (2002), Social Connections in China: Institutions, Culture and the Changing Nature of Guanxi, Cambridge University Press, Cambridge. 
Gould-Williams, J. (2003), "The importance of HR practices and workplace trust in achieving superior performance: a study of public-sector organizations", International Journal of Human Resource Management, Vol. 14 No. 1, pp. 28-54.

Grant, R. (1996), "Toward a knowledge-based theory of the firm”, Strategic Management Journal, Vol. 17 No. 1, pp. 109-22.

Greif, A. (1994), "Cultural beliefs and the organization of society: a historical and theoretical reflection on collectivist and individualist societies", Journal of Political Economy, Vol. 102, pp. 912-50.

Guthrie, J., Petty, R., and Ricceri, F. (2006), "The voluntary reporting of intellectual capital: comparing evidence from Hong Kong and Australia”, Journal of Intellectual Capital, Vol. 7 No. 2, pp. 254-71.

Guthrie, J., Petty, R., Yongvanich, K., and Ricceri, F. (2004), "Using content analysis as a research method to inquire into intellectual capital reporting”, Journal of Intellectual Capital, Vol. 5 No. 2 , pp. 282-93.

Guthrie, J., Ricceri, F. and Dumay, J. (2012), "Reflections and projections: a decade of intellectual capital accounting research”, The British Accounting Review, Vol. 44 No. 2, pp. 68-82.

Hair, J.F., Black, W.C., Rabin, B.J., Anderson, R.E. and Tatham, R.L. (2006), Multivariate Data Analysis, 6th ed., Pearson Education, New Jersey.

Hamilton, K. (2006), Where is the Wealth of Nations? Measuring Capital for the 21st Century, World Bank Publications, Washington, DC.

Hofstede, G. (1980), Culture's Consequences: International Differences in Work-Related Values, Sage, Beverly Hills.

Hofstede, G., Hofstede, G.J. and Minkov, M. (2010), Cultures and Organizations: Software of the Mind, 3rd ed., McGraw-Hill Professional, New York.

Holmes, R.M., Miller T., Hitt, M.A. and Salmador, M.P. (2013), “The interrelationships among informal institutions, formal institutions, and inward foreign direct investment", Journal of Management, Vol. 39 No. 2, pp. 531-66.

Hormiga, E., Batista-Canino, R.M. and Sánchez-Medina, A. (2011), "The role of intellectual capital in the success of new ventures", International Entrepreneurship and Management Journal, Vol. 7 No. 1, pp. 71-92.

Hsu, I.-C. and Sabherwal, R. (2012), "Relationship between intellectual capital and knowledge management: an empirical investigation”, Decision Sciences, Vol. 43 No. 3, pp. 489-524. 
Hsu, Y.-H. and Fang, W. (2009), "Intellectual capital and new product development performance: the mediating role of organizational learning capability", Technological Forecasting and Social Change, Vol. 76 No. 5, pp. 664-77.

Huang, C.C., Luther, R. and Tayles, M. (2007), "An evidence-based taxonomy of intellectual capital”, Journal of Intellectual Capital, Vol. 8 No. 3, pp. 386-408.

Huber, G. (1991), "Organizational learning: the contributing processes and the literatures", Organization Science, Vol. 2 No. 1, pp. 88-115.

Hughes, M. and Morgan, R.E. (2007), "Deconstructing the relationship between entrepreneurial orientation and business performance at the embryonic stage of firm growth", Industrial Marketing Management, Vol. 36 No. 5, pp. 651-61.

Hurley, R.F. and Hult, G.T.M. (1998), "Innovation, market orientation, and organizational learning: an integration and empirical examination", Journal of Marketing, Vol. 62 No. 3, pp. 4254 .

Inglehart, R. and Baker, W.E. (2000), "Modernization, cultural change, and the persistence of traditional values", American Sociological Review, Vol. 65 No. 1, pp. 19-51.

Inkinen, H. (2015), "Review of empirical research on intellectual capital", Journal of Intellectual Capital, Vol. 16 No. 3, pp. 518-65.

Inkinen, H., Kianto, A., Vanhala, M. and Ritala, P. (2014), "Intellectual capital and performance: empirical findings from Finnish firms", in Carlucci, D., Spender, J.C. and Schiuma, G. (Eds.), Knowledge and Management Models for Sustainable Growth, International Forum on Knowledge Asset Dynamics, Matera, Italy, pp. 2918-33.

Kale, P., Singh, H. and Perlmutter, H. (2000), "Learning and protection of proprietary assets in strategic alliances: building relational capital", Strategic Management Journal, Vol. 21, pp. 21737.

Kamukama, N., Ahiauzu, A. and Ntayi, J.M. (2011), "Competitive advantage: mediator of intellectual capital and performance", Journal of Intellectual Capital, Vol. 12 No. 1, pp. 152-64.

Kaufmann, L. and Schneider, Y. (2004), "Intangibles. A synthesis of current research”, Journal of Intellectual Capital, Vol. 5 No. 3, pp. 366-88.

Kianto, A. (2007), "What do we really mean by the dynamic dimension of intellectual capital?", International Journal of Learning and Intellectual Capital, Vol. 4 No. 4, pp. 342-56.

Kianto, A. (2008), "Development and validation of a survey instrument for measuring organizational renewal capability", International Journal of Technology Management, Vol. 42 Nos. 1/2, pp. 69-88. 
Kianto, A., Hurmelinna-Laukkanen, P. and Ritala, P. (2010), "Intellectual capital in service- and product-oriented companies”, Journal of Intellectual Capital, Vol. 11 No. 3, pp. 305-25.

Korhonen, J. and Seppälä, N. (2005), "The strength of a high-trust society”, in Habisch, A., Jonker, J., Wegner, M. and Schmidpeter, R. (Eds.), Corporate Social Responsibility Across Europe, Springer-Verlag, Berlin-Heidelberg, pp. 13-22.

Lin, C.Y.-Y. and Edvinsson, L. (2008), "National intellectual capital: comparison of the Nordic countries”, Journal of Intellectual Capital, Vol. 9 No. 4, pp. 525-45.

Lin, C.Y.-Y. and Edvinsson, L. (2011), National Intellectual Capital: A Comparison of 40 Countries, Springer, New York, NY.

Lin, C.Y.-Y. and Edvinsson, L. (2012), "National intellectual capital model and measurement", International Journal of Knowledge-Based Development, Vol. 3 No. 1, pp. 58-82.

Lumpkin G.T. and Dess, G. (1996), "Clarifying the entrepreneurial orientation construct and linking it to performance”, Academy of Management Review, Vol. 21 No. 1, pp. 135-72.

MacArthur, J. (2006), "Cultural influences on German versus U.S. management accounting practices", Management Accounting Quarterly, Vol. 7 No. 2, pp. 10-6.

Maditinos, D., Šević, Z. and Tsairidis, C. (2010), "Intellectual capital and business performance: an empirical study for the Greek listed companies", European Research Studies Journal, Vol. 13 No. 3, pp. 145-67.

Maguire, K. B. (2009), "Does mode matter? A comparison of telephone, mail, and in-person treatments in contingent valuation surveys", Journal of Environmental Management, Vol. 90, pp. 3528-33.

Mayer, R.C., Davis, J.H. and Schoorman, F.D. (1995), “An integrative model of organizational trust”, Academy of Management Review, Vol. 20 No. 3, pp. 709-34.

Mention, A.-L. and Bontis, N. (2013), "Intellectual capital and performance within the banking sector of Luxembourg and Belgium”, Journal of Intellectual Capital, Vol. 14 No. 2, pp. 286-309.

Mouritsen, J. (2006), "Problematising intellectual capital research: ostensive versus performative IC", Accounting, Auditing and Accountability Journal, Vol. 19 No. 6, pp. 820-41.

Mouritsen, J. and Larsen, H. (2005), "The 2nd wave of knowledge management: the management control of knowledge resources through intellectual capital information", Management Accounting Research, Vol. 16 No. 3, pp. 371-94.

Mouritsen, J., Larsen, H.T. and Bukh, P.N.D. (2001), “Intellectual capital and the 'capable firm': narrating, visualising and numbering for managing knowledge", Accounting, Organizations and Society, Vol. 26 No. 7, pp. 735-62. 
Munch, P.A. (1964), "Culture and superculture in a displaced community: Tristan da Cunha", Ethnology, Vol. 3 No. 1, pp. 369-76.

Nahapiet, J. and Ghoshal, S. (1998), "Social capital, intellectual capital and the organizational advantage", The Academy of Management Review, Vol. 23 No. 2, pp. 242-66.

Nazari, J., Herremans, R., Manassian, I., and Kline, T. (2009), "Organizational characteristics fostering intellectual capital in Canada and the Middle East", Journal of Intellectual Capital, Vol. 10 No. 1, pp. 135-48.

Nonaka, I. and Takeuchi, H. (1995), The Knowledge-Creating Company, Oxford University Press, New York, NY.

North, D.C. (1990), Institutions, Institutional Change and Economic Performance, Cambridge University Press, Cambridge.

Peng, M.W., Wang, D.Y. and Jiang, Y. (2008), "An institution-based view of international strategy: a focus on emerging markets", Journal of International Business Studies, Vol. 39 No. 5 , pp. 920-36.

Petty, R. and Guthrie, J. (2000), "Intellectual capital literature review: measurement, reporting and management”, Journal of Intellectual Capital, Vol. 1 No. 2, pp.155-76.

Pulic, A. (2000), "VAICTM_an accounting tool for IC management", International Journal of Technology Management, Vol. 20 No. 5-8, pp. 702-14.

Ricceri, F. (2008), Intellectual Capital and Knowledge Management: Strategic Management of Knowledge Resources, Routledge, Milton Park, UK.

Roos, G. and Roos, J. (1997), “Measuring your company's intellectual performance”, Long Range Planning, Vol. 30 No. 3, pp. 413-26.

Roslender, R. and Fincham, R. (2001), "Thinking critically about intellectual capital accounting", Accounting, Auditing \& Accountability Journal, Vol. 14 No. 4, pp. 383-99.

Rousseau, D.M., Sitkin, S.B., Burt, R.S. and Camerer, C.F. (1998), "Not so different after all: a cross-discipline view of trust", Academy of Management Review, Vol. 23 No. 3, 393-404.

Scott, R.W. (1995), Institutions and Organizations, SAGE Publications, Thousand Oaks.

Sharabati, A.-A.A., Jawad, S.N. and Bontis, N. (2010), "Intellectual capital and business performance in the pharmaceutical sector of Jordan", Management Decision, Vol. 48 No. 1, pp. 105-31.

Smith, H.J., Milberg, S.J. and Burke, S.J (1996), “Information privacy: measuring individuals' concerns about organizational practices”, MIS Quarterly, Vol. 20 No. 2, pp. 167-96. 
Stewart, T. (1997), Intellectual Capital: The New Wealth of Organizations, Doubleday, New York, NY.

Subramaniam, M. and Youndt, M.A. (2005), "The influence of intellectual capital on the types of innovative capabilities", Academy of Management Journal, Vol. 48 No. 3, pp. 450-63.

Sullivan, P. (1998), Profiting from Intellectual Capital: Extracting Value from Innovation, Wiley, New York, NY.

Sveiby, K.E. (1997), The New Organizational Wealth: Managing and Measuring Knowledgebased Assets, Berrett-Koehlen, New York, NY.

Szolnoki, G. and Hoffman, D. (2013), "Online, face-to-face and telephone surveys - comparing different sampling methods in wine consumer research", Wine Economics and Policy, Vol. 2 No. 2, pp. 57-66.

Tayles, M., Bramley, A., Adshead, N. and Farr, J. (2002), "Dealing with the management of intellectual capital: the potential role of strategic management accounting", Accounting, Auditing \& Accountability Journal, Vol. 15 No. 2, pp. 251-67.

Tayles, M., Pike, R. and Sofian, S. (2007), "Intellectual capital, management accounting practices and corporate performance: perceptions of managers", Accounting, Auditing \& Accountability Journal, Vol. 20 No. 4, pp. 522-48.

Tolbert, P.S. and Zucker, L. (1996), "The institutionalization of institutional theory", in Clegg, S.R., Hardy, C. and Nord, W. (Eds.), Handbook of Organizational Studies, Sage, London, pp. 75190.

Tovstiga, G. and Tulugurova, E. (2009), "Intellectual capital practices: a four-region comparative study”, Journal of Intellectual Capital, Vol. 10 No. 1, pp. 70-80.

Trompenaars, F. (1993), Riding the Waves of Culture: Understanding Cultural Diversity in Business, The Economist Books, London.

Tseng, C.-Y. and Goo, Y.-J.J. (2005), "Intellectual capital and corporate value in an emerging economy: empirical study of Taiwanese manufacturers", R\&D Management, Vol. 35 No. 2, pp.187-201.

Tzafrir, S.S. (2005), "The relationship between trust, HRM practices and firm performance". International Journal of Human Resource Management, Vol. 16 No. 9, pp. 1600-22.

Vandemaele, S.N., Vergauwen, P.G.M.C. and Smits, A.J. (2005), "Intellectual capital disclosure in the Netherlands, Sweden and the UK: a longitudinal and comparative study", Journal of Intellectual Capital, Vol. 6 No. 3, pp. 417-26.

Vanhala, M., Puumalainen, K. and Blomqvist, K. (2011), "Impersonal trust - the development of the construct and the scale", Personnel Review, Vol. 40 No. 4, 485-513. 
Yang, C. and Lin, C. (2009), "Does intellectual capital mediate the relationship between HRM and organizational performance? Perspective of a healthcare industry in Taiwan", International Journal of Human Resource Management, Vol. 20 No. 9, pp. 1965-84.

Yli-Renko, H., Autio, E. and Tontti, V. (2002), "Social capital, knowledge, and the international growth of technology-based new firms", International Business Review, Vol. 11 No. 3, pp. 279304.

Youndt, M.A., Subramaniam, M. and Snell, S.A. (2004), "Intellectual capital profiles: an examination of investments and returns", Journal of Management Studies, Vol. 41 No. 2, pp. 33561.

Zollo, M. and Winter, S.G. (2002), "Deliberate learning and the evolution of dynamic capabilities", Organization Science, Vol. 13 No. 3, pp. 339-51. 
Appendix 1. Measurement items, factor loadings and model fit indices.

\begin{tabular}{|c|c|c|c|c|c|c|c|}
\hline & $\begin{array}{l}\text { Key } \\
\text { sources } \\
\text { for the } \\
\text { scale }\end{array}$ & $\begin{array}{l}\text { To what extent do the following } \\
\text { statements on... apply to your } \\
\text { company? }(1=\text { completely } \\
\text { disagree, } 5 \text { = completely agree })\end{array}$ & $\begin{array}{l}\text { Finland } \\
(\mathrm{N}=259)\end{array}$ & $\begin{array}{c}\text { Spain } \\
(\mathrm{N}=180)\end{array}$ & $\begin{array}{l}\text { Serbia } \\
(\mathrm{N}=\mathbf{8 0})\end{array}$ & $\begin{array}{l}\text { Russia } \\
(\mathrm{N}=87)\end{array}$ & $\begin{array}{c}\text { Italy } \\
(\mathrm{N}=102)\end{array}$ \\
\hline \multirow{5}{*}{$\begin{array}{l}\text { Internal } \\
\text { relational } \\
\text { capital }\end{array}$} & \multirow{5}{*}{$\begin{array}{l}\text { Adapted } \\
\text { from } \\
\text { Kianto } \\
\text { (2008) and } \\
\text { inspired by } \\
\text { Yang and } \\
\text { Lin (2009) }\end{array}$} & $\begin{array}{l}\text { Different units and functions } \\
\text { within our company - such as } \\
\text { R\&D, marketing and production } \\
\text { - understand each other well }\end{array}$ & $0.616^{\mathrm{a}}$ & $0.766^{\mathrm{a}}$ & $0.751^{\mathrm{a}}$ & $0.812^{\mathrm{a}}$ & $0.826^{\mathrm{a}}$ \\
\hline & & $\begin{array}{l}\text { Our employees frequently } \\
\text { collaborate to solve problems. }\end{array}$ & $0.771 * * *$ & $0.807 * * *$ & - & - & - \\
\hline & & $\begin{array}{l}\text { Internal cooperation in our } \\
\text { company runs smoothly. }\end{array}$ & $0.721 * * *$ & $0.874 * * *$ & $0.886 * * *$ & $0.737 * * *$ & $0.697 * * *$ \\
\hline & & CR & 0.75 & 0.86 & 0.8 & 0.75 & 0.74 \\
\hline & & AVE & 0.5 & 0.67 & 0.67 & 0.6 & 0.58 \\
\hline \multirow{5}{*}{$\begin{array}{l}\text { External } \\
\text { relational } \\
\text { capital }\end{array}$} & \multirow{5}{*}{$\begin{array}{l}\text { Adapted } \\
\text { from } \\
\text { Kianto } \\
(2008) \text { and } \\
\text { Kianto et } \\
\text { al. (2010) }\end{array}$} & $\begin{array}{l}\text { Our company and its external } \\
\text { stakeholders - such as } \\
\text { customers, suppliers and } \\
\text { partners - understand each other } \\
\text { well. }\end{array}$ & $0.62^{\mathrm{a}}$ & $0.756^{\mathrm{a}}$ & $0.678^{\mathrm{a}}$ & $0.73^{\mathrm{a}}$ & $0.774^{\mathrm{a}}$ \\
\hline & & $\begin{array}{l}\text { Our company and its external } \\
\text { stakeholders frequently } \\
\text { collaborate to solve problems. }\end{array}$ & $0.776 * * *$ & $0.708 * * *$ & $0.61 * * *$ & $0.598 * * *$ & $0.851 * * *$ \\
\hline & & $\begin{array}{l}\text { Cooperation between our } \\
\text { company and its external } \\
\text { stakeholders runs smoothly. }\end{array}$ & $0.776 * * *$ & $0.851 * * *$ & $0.841 * * *$ & $0.714 * * *$ & $0.935 * * *$ \\
\hline & & CR & 0.77 & 0.82 & 0.76 & 0.72 & 0.89 \\
\hline & & AVE & 0.53 & 0.6 & 0.51 & 0.47 & 0.73 \\
\hline \multirow{6}{*}{$\begin{array}{l}\text { Structural } \\
\text { capital }\end{array}$} & \multirow{6}{*}{$\begin{array}{l}\text { Adapted } \\
\text { from } \\
\text { Kianto } \\
(2008) \text { and } \\
\text { Kianto et } \\
\text { al. (2010) }\end{array}$} & $\begin{array}{l}\text { Our company has efficient and } \\
\text { relevant information systems to } \\
\text { support business operations. }\end{array}$ & $0.518^{\mathrm{a}}$ & $0.694^{\mathrm{a}}$ & $0.712^{\mathrm{a}}$ & $0.777^{\mathrm{a}}$ & $0.731^{\mathrm{a}}$ \\
\hline & & $\begin{array}{l}\text { Our company has tools and } \\
\text { facilities to support cooperation } \\
\text { between employees. }\end{array}$ & $0.602 * * *$ & $0.784 * * *$ & $0.784 * * *$ & $0.87 * * *$ & $0.767 * * *$ \\
\hline & & $\begin{array}{l}\text { Our company has a great deal of } \\
\text { useful knowledge in documents } \\
\text { and databases. }\end{array}$ & $0.679 * * *$ & $0.741 * * *$ & - & - & - \\
\hline & & $\begin{array}{l}\text { Existing documents and } \\
\text { solutions are easily accessible. }\end{array}$ & - & - & - & - & - \\
\hline & & $\mathbf{C R}$ & 0.63 & 0.78 & 0.72 & 0.81 & 0.72 \\
\hline & & AVE & 0.36 & 0.55 & 0.56 & 0.68 & 0.56 \\
\hline \multirow{5}{*}{ Human capital } & \multirow{5}{*}{$\begin{array}{l}\text { Bontis } \\
(1998) \text {; } \\
\text { Yang and } \\
\text { Lin }(2009)\end{array}$} & $\begin{array}{l}\text { Our employees are highly } \\
\text { skilled at their jobs. }\end{array}$ & $0.736^{\mathrm{a}}$ & $0.761^{\mathrm{a}}$ & $0.891^{\mathrm{a}}$ & $0.832^{\mathrm{a}}$ & $0.864^{\mathrm{a}}$ \\
\hline & & $\begin{array}{l}\text { Our employees are highly } \\
\text { motivated in their work. }\end{array}$ & $0.626 * * *$ & - & - & - & - \\
\hline & & $\begin{array}{l}\text { Our employees have a high } \\
\text { level of expertise. }\end{array}$ & $0.827 * * *$ & $0.816 * * *$ & $0.646 * * *$ & $0.851 * * *$ & $0.57 * * *$ \\
\hline & & CR & 0.78 & 0.77 & 0.75 & 0.83 & 0.69 \\
\hline & & AVE & 0.54 & 0.62 & 0.61 & 0.71 & 0.54 \\
\hline
\end{tabular}




\begin{tabular}{|c|c|c|c|c|c|c|c|}
\hline \multirow{6}{*}{ Renewal capital } & \multirow{6}{*}{$\begin{array}{l}\text { Hughes } \\
\text { and } \\
\text { Morgan } \\
\text { (2007); } \\
\text { Kianto et } \\
\text { al. } \\
\text { (2010); } \\
\text { García- } \\
\text { Morales } \\
\text { and } \\
\text { Llorens- } \\
\text { Montes } \\
\text { (2006) }\end{array}$} & $\begin{array}{l}\text { Our company has acquired a } \\
\text { great deal of new and important } \\
\text { knowledge. }\end{array}$ & $0.613^{\mathrm{a}}$ & $0.728^{\mathrm{a}}$ & - & $0.82^{\mathrm{a}}$ & $0.791^{\mathrm{a}}$ \\
\hline & & $\begin{array}{l}\text { Our employees have acquired a } \\
\text { great deal of important skills } \\
\text { and abilities. }\end{array}$ & - & - & - & - & - \\
\hline & & $\begin{array}{l}\text { Our company can be described } \\
\text { as a learning organisation. }\end{array}$ & $0.748 * * *$ & $0.891 * * *$ & - & $0.796 * * *$ & $0.822 * * *$ \\
\hline & & $\begin{array}{l}\text { The operations of our company } \\
\text { can be described as creative and } \\
\text { inventive. }\end{array}$ & $0.773 * * *$ & - & - & - & - \\
\hline & & CR & 0.76 & 0.8 & - & 0.79 & 0.78 \\
\hline & & AVE & 0.51 & 0.66 & - & 0.65 & 0.64 \\
\hline \multirow{7}{*}{ Trust capital } & \multirow{7}{*}{$\begin{array}{l}\text { Develop } \\
\text { ed by the } \\
\text { authors } \\
\text { with the } \\
\text { conceptu } \\
\text { al } \\
\text { inspirati } \\
\text { on from } \\
\text { Mayer et } \\
\text { al. } \\
\text { (1995) } \\
\text { and } \\
\text { Vanhala } \\
\text { et al. } \\
\text { (2011) }\end{array}$} & $\begin{array}{l}\text { The way our company operates } \\
\text { is characterised by an } \\
\text { atmosphere of trust. }\end{array}$ & $0.73^{\mathrm{a}}$ & - & - & - & - \\
\hline & & $\begin{array}{l}\text { We keep our promises and } \\
\text { agreements. }\end{array}$ & $0.677 * * *$ & - & - & - & - \\
\hline & & $\begin{array}{l}\text { Our company seeks to take the } \\
\text { interests of its stakeholders into } \\
\text { account in its operations. }\end{array}$ & $0.603 * * *$ & - & - & - & - \\
\hline & & $\begin{array}{l}\text { The expertise of our company } \\
\text { inspires trust in stakeholders. }\end{array}$ & $0.613 * * *$ & - & - & - & - \\
\hline & & $\begin{array}{l}\text { The image and reputation of our } \\
\text { company inspire trust in } \\
\text { stakeholders. }\end{array}$ & 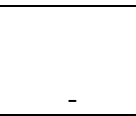 & - & - & - & - \\
\hline & & $\mathbf{C R}$ & 0.75 & - & - & - & - \\
\hline & & AVE & 0.43 & - & - & - & - \\
\hline \multirow{8}{*}{$\begin{array}{l}\text { Entrepreneurial } \\
\text { capital }\end{array}$} & \multirow{8}{*}{$\begin{array}{l}\text { Inspired } \\
\text { by } \\
\text { Hughes } \\
\text { and } \\
\text { Morgan } \\
(2007)\end{array}$} & $\begin{array}{l}\text { Risk-taking is regarded as a } \\
\text { positive personal quality in our } \\
\text { company. }\end{array}$ & - & - & - & - & - \\
\hline & & $\begin{array}{l}\text { Our employees take deliberate } \\
\text { risks related to new ideas. }\end{array}$ & - & - & - & - & - \\
\hline & & $\begin{array}{l}\text { Our employees are excellent at } \\
\text { identifying new business } \\
\text { opportunities. }\end{array}$ & $0.746^{\mathrm{a}}$ & $0.633^{\mathrm{a}}$ & $0.72^{\mathrm{a}}$ & $0.751^{\mathrm{a}}$ & $0.843^{\mathrm{a}}$ \\
\hline & & Our employees show initiative. & $0.745 * * *$ & $0.764 * * *$ & $0.828 * * *$ & $0.792 * * *$ & $0.944 * * *$ \\
\hline & & $\begin{array}{l}\text { The operations of our company } \\
\text { are defined by independence } \\
\text { and freedom in performing } \\
\text { duties. }\end{array}$ & - & - & - & - & - \\
\hline & & $\begin{array}{l}\text { Our employees have the } \\
\text { courage to make bold and } \\
\text { difficult decisions. }\end{array}$ & $0.752 * * *$ & $0.755 * * *$ & $0.701 * * *$ & $0.764 * * *$ & $0.819 * * *$ \\
\hline & & $\mathbf{C R}$ & 0.79 & 0.76 & 0.8 & 0.82 & 0.9 \\
\hline & & AVE & 0.56 & 0.52 & 0.57 & 0.59 & 0.76 \\
\hline \multirow{7}{*}{\multicolumn{2}{|c|}{ Model fit indices }} & Chi-square (df) & $\begin{array}{c}326.97 \\
(188) \\
\end{array}$ & $\begin{array}{c}160.04 \\
(89)\end{array}$ & $\begin{array}{c}48.23 \\
(44) \\
\end{array}$ & $\begin{array}{c}59.22 \\
(62) \\
\end{array}$ & $\begin{array}{c}80.80 \\
(62) \\
\end{array}$ \\
\hline & & p-value & 0 & 0 & 0.306 & 0.577 & 0.05463 \\
\hline & & RMSEA & 0.054 & 0.067 & 0.035 & 0 & 0.055 \\
\hline & & GFI & 0.897 & 0.899 & 0.908 & 0.91 & 0.897 \\
\hline & & CFI & 0.978 & 0.976 & 0.993 & 0.996 & 0.977 \\
\hline & & NNFI & 0.973 & 0.967 & 0.99 & 0.995 & 0.966 \\
\hline & & IFI & 0.978 & 0.976 & 0.993 & 0.997 & 0.978 \\
\hline
\end{tabular}

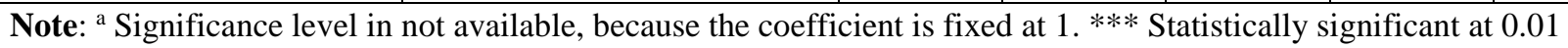
significance level. 